\title{
Pharmacognostical Investigation and Preliminary Phytochemi- cal Screening of Leaves of Myxopyrum Smilacifolium B.
}

\author{
Raveesha Peeriga ${ }^{1}$ and Chandrasekhar Kothapalli Bonnth ${ }^{2}$ \\ 'Department of Pharmacognosy, V. V. Institute of Pharmaceutical Sciences, Gudlavalleru, Andhra Pradesh, INDIA. \\ ${ }^{2}$ Department of Chemistry, Professor of Chemistry \& Director of JNTUA-OTRI, Ananthapur, Andhra Pradesh, INDIA.
}

\begin{abstract}
Objective: The current study deals with detailed pharmacognostical study and preliminary phytochemical screening of leaf of Myxopyrum smilacifolium Blume. Myxopyrum smilacifolium Blume is a twining shrub belongs to the family Oleaceae. It is used traditionally in the treatment of cough, rheumatism, cephalalgia, notalagia and otopathy. Scrutinization of literature revealed that there is a lack of pharmacognostical and Phytochemical investigations of Myxopyrum smilacifolium Blume. Methods: The macroscopical and microscopical features were evaluated. The leaves of Myxopyrum smilacifolium Blume was subjected for successive solvent extraction and further preliminary phytochemical screening was carried out and also the behaviour of powder with different reagents were evaluated by fluorescence analysis. Results: The detailed study of pharmacognostical evaluation showed the presence of thick walled epidermal cells covered with thick cuticle, xylem and phloem elements, Glandular trichome and slightly concave collateral vascular bundles. Preliminary Phytochemical examination revealed the presence of various phytoconstituents viz., alkaloids, gly-
\end{abstract}

cosides, tannins, saponins, terpenoids, carbohydrates and fixed oils. The fluorescence analysis manifested the behavioral variation of the powdered drug. Conclusion: The findings of the present study will be a referential information for identification and also useful for standardization of the plant material.

Key words: Oleaceae, Microscopy, Phytochemical screening, Standardization, Myxopyrum.

\section{Correspondence:}

Mrs. Raveesha Peeriga, M Pharm. Department of Pharmacognosy, V. V. Institute of Pharmaceutical Sciences, Gudlavalleru, Andhra Pradesh, INDIA.

Phone: +918297509909

E-mail: raveesha.peeriga@gmail.com

DOI: $10.5530 /$ pj.2016.2.10

\section{INTRODUCTION}

Myxopyrum smilacifolium Blume $e^{1}$ is a large woody twining shrub commonly called as chaturdharalata in telugu. The leaf of this plant is used traditionally for the treatment of rheumatism, cough, cephalalgia, notalagia, anodyne, febrifuge and otopathy. Vegatatively, the genus Myxopyrum is very distinct plant belonging to the family Oleaceae. The anatomical and chemical investigations on Myxopyrum genus are very limited. Myxopyrum smilacifolium Blume grows at an altitude of below 700-1000 m. Relating to Myxopyrum species 6 taxas are recognized. ${ }^{2}$ Among them one of the species is Myxopyrum smilacifolium Blume. It is distributed at tropical and subtropical regions of Eastern Asia. Earlier investigation was made on a single leaf of Myxopyrum smilacifolium and reported that it contains irridoid glucosides and triterpenoids. ${ }^{3}$ In Ayurveda the herb is used in vitiated conditions of Kapha and vata.

\section{MATERIAL AND METHODS}

\section{Plant material}

Myxopyrum smilacifolium Blume leaves were procured from botanical garden, Department of Botany, University of Kerala, Kerala. It was identified and authenticated by V. Chelladurai, Former Research officer. Central Council of Research in Ayurveda and Siddha, Government Siddha medical College, Tamil Nadu. India.

\section{Description of the plant}

The plant is twinning which grows in exposed areas like open thickets or seashores. Leaf is elliptical to ovate, petiolate and measures about (9-) $12-17(-24.5) \times 4.5-8(-10) \mathrm{cm}$, glabrous, base rounded and apex acuminate. Margin is serrate towards apex region but may be entire or spinose. It shows terminal inflorescence and flowers are yellow in color, subsessile. Fruit is globose, measures about $5 \times 5-10 \times 13 \mathrm{~mm}$. Seeds are 1-2. In Calyx lobes are ovate-acute and pubescent. Corolla, the lobes are linear openly recurved. Stamens are subsessile and anthers are elliptic.

\section{Pharmacognostic evaluation Organoleptic evaluation}

The sensory parameters of leaf of Myxopyrum smilacifolium Blume such as size, shape, color, odour and taste were recorded.

\section{Microscopic evaluation Preparation of sections}

The sections of leaf were made with the help of rotary microtome. Later the sections were made stained with toluidine blue, a polychromatic stain. ${ }^{4}$ The cleared sections were then mounted with glycerin for microscopical observations.

\section{Powder microscopy}

To a little quantity of powder in a watch glass, $1-2$ drops of $0.1 \%$ phloroglucinol solution and Concentrated HCL was added in a ratio of 1:1. The stained powder was transferred onto a slide, mounted with glycerol and covered with cover slip. ${ }^{5}$ The prepared slide observed under microscope with $10 \times 10$ magnifications. The presence of starch grains were detected by addition of 2-3 drops of $0.01 \mathrm{~m}$ Iodine solution.

\section{Determination of Stomatal Index}

Leaf fragments of about $5 \times 5 \mathrm{~mm}$ in size were taken and it was cleared with chloral hydrate solution. ${ }^{6-7}$ The cleared fragment of leaf was mounted with glycerol on microscopic slide. It is observed under microscope for quantification of Stomatal Number and Stomatal Index, vein islet number and Vein termination number. The slide was examined with $40 \mathrm{x}$ objective and $6 \mathrm{x}$ eye piece to which a Camera lucida was attached and recorded.

\section{Physical evaluation Estimation of crude fiber}

$2 \mathrm{gm}$ of powdered drug was taken and $50 \mathrm{ml}$ of $10 \% \mathrm{v} / \mathrm{v}$ nitric acid was added. It was heated with constant stirring and strained. To the residue $50 \mathrm{ml}$ of $2.5 \% \mathrm{v} / \mathrm{v}$ sodium hydroxide solution was added, heated and 
maintained at boiling point for 30 seconds. ${ }^{5}$ After it was strained and the residue is weighed. The percentage of crude fibers was determined.

\section{Moisture content}

$10 \mathrm{gm}$ of accurately weighed fresh leaves of Myxopyrum smilacifolium Blume was placed in a tared porcelain dish and dried at $105^{\circ} \mathrm{C}$ for $5 \mathrm{hrs}$ and weighed. Drying and weighing is continued at an interval of one hour until two successive weighing is constant.

\section{Total ash Determination of total ash}

$2 \mathrm{gm}$ of leaf powder of Myxopyrum smilacifolium Blume was taken in tared silica crucible and incinerated at a temperature not more than $450^{\circ} \mathrm{C}$ until free from carbon. The obtained ash was cooled and weighed. The percentage of ash was calculated with reference to the air dried drug. ${ }^{7}$

\section{Acid-insoluble ash}

The total ash obtained from 2 gm of leaf powder was boiled with $25 \mathrm{ml}$ of dilute hydrochloric acid for 5 minutes and the insoluble mater was collected on an ashless filter paper. It was washed, ignited and weighed. The percentage of acid insoluble ash was calculated with reference to the air dried drug.

\section{Water soluble ash}

The total ash obtained from $2 \mathrm{~g}$ of leaf powder was boiled with $25 \mathrm{ml}$ of water for 5 minutes and the insoluble matter was collected on an ashless filter paper. It was washed, ignited and weighed. The percentage of water soluble ash was calculated with reference to the air dried drug.

\section{Determination of alcohol soluble extractive}

$5 \mathrm{~g}$ of accurately weighed leaves was taken and macerated with $100 \mathrm{ml}$ of $95 \%$ alcohol for $24 \mathrm{hr}$. The contents were frequently shaken during the first $6 \mathrm{hr}$ and allowed to stand for $18 \mathrm{hr}$. After $24 \mathrm{hr}, 25 \mathrm{ml}$ of extract was filtered and evaporated. The extract was dried at $105^{\circ} \mathrm{C}$ to a constant weight.

\section{Determination of water soluble extractive}

$5 \mathrm{~g}$ of accurately weighed leaves was taken and macerated with $100 \mathrm{ml}$ of chloroform water for $24 \mathrm{hr}$. The contents were frequently shaken during the first $6 \mathrm{hr}$ and allowed to stand for $18 \mathrm{hr}$. After $24 \mathrm{hr}, 25 \mathrm{ml}$ of extract was filtered and evaporated. The extract was dried at $105^{\circ} \mathrm{C}$ to a constant weight.

\section{Preparation of extract}

$500 \mathrm{~g}$ of dried coarsely powdered leaf of Myxopyrum smilacifolium Blume was packed in soxhlet apparatus and was defatted with petroleum ether $\left(50-60^{\circ} \mathrm{C}\right)$. The marc left subsequently extracted with Petroleum ether, chloroform, methanol and distilled water. The extracts obtained were concentrated using rotary evaporator and dried.

\section{Preliminary Phytochemical Screening}

The extracts were subjected to preliminary Phytochemical screening for the detection of various plant constituents viz. carbohydrates, fixed oils, alkaloids, glycosides, terpenoids, flavonoids, tannins and phenols. ${ }^{9-13}$

\section{Fluorescence analysis of the powdered drug}

The fluorescence analysis of the powdered leaves was done by placing dry powdered leaves on a slide and observed by treating with several drops of different chemical reagents to detect the color changes under $\mathrm{UV}$ and Visible light. ${ }^{3}$

\section{RESULTS}

\section{Pharmacognostic evaluation Organoleptic and Microscopic evaluation}

Macroscopically, the leaf of Myxopyrum smilacifolium Blume is simple, shape is elliptical, petiolate, opposite in arrangement, apex is acuminate, margin is obscurely serrate towards apex and base is rounded. Fresh leaves are green in color and measures about $10-14 \mathrm{~cm}$ in length and $3-4 \mathrm{~cm}$ in width. The leaf powder was green in color with characteristic odor and bitter taste. (Figure 1)

The microscopical examination of leaf was revealed the presence of thick walled epidermal cells covered with thick cuticle, slightly concave collateral vascular bundles, Glandular trichome is a capitate type embedded in the epidermis where the rosette arrangement of cells were observed in surface view of epidermis and anomocytic type of stomata. (Figures 2, 3 \& 4)

The powdered microscopical examination of leaf of Myxopyrum smilacifolium Blume revealed that the presence of xylem, phloem elements and palisade cells. (Figure 5)

The quantitative microscopical evaluation of fresh leaves and leaf powder was performed and the results were obtained. (Table 1)

\section{Physical evaluation}

The various physical parameters of leaves and leaf powder viz., Crude fiber content, moisture content, Ash values and extractive values were determined. (Table 2)

The quantitative and qualitative pharmacognostical study helps in identification of the plant as these values are unique for each and every species of plant and they acquire an utmost important in standardization of crude drug.

\section{Preliminary Phytochemical Screening}

The preliminary phytochemical screening for the extracts viz., petroleum ether, chloroform, methanol and water was carried out and the results obtained. (Table 3)

\section{Flourescene analysis}

The behavioral changes of powdered drug with different chemical reagents were determined at both UV and Visible light and it is reported. (Table 4)

\section{DISCUSSION}

In the present study, pharmacognostical parameters of leaf of Myxopyrum smilacifolium Blume were evaluated which serves as an establishment for the monograph of the crude drug. The fluorescence analysis of the powdered leaf was examined and the various behavioral changes had observed with different reagents at both UV and Visible light. The phytochemical analysis of different solvent extracts viz., petroleum ether, chloroform, methanol and water were examined and it revealed the presence of various secondary metabolites which gains an importance in medicine.

\section{CONCLUSION}

In the current investigation, the pharmacognostical investigation, physicochemical parameters and fluorescence analysis and preliminary phytochemical screening of Myxopyrum smilacifolium Blume was carried out. The results of current study help as a reference material to develop a monograph. The preliminary phytochemical screening of 


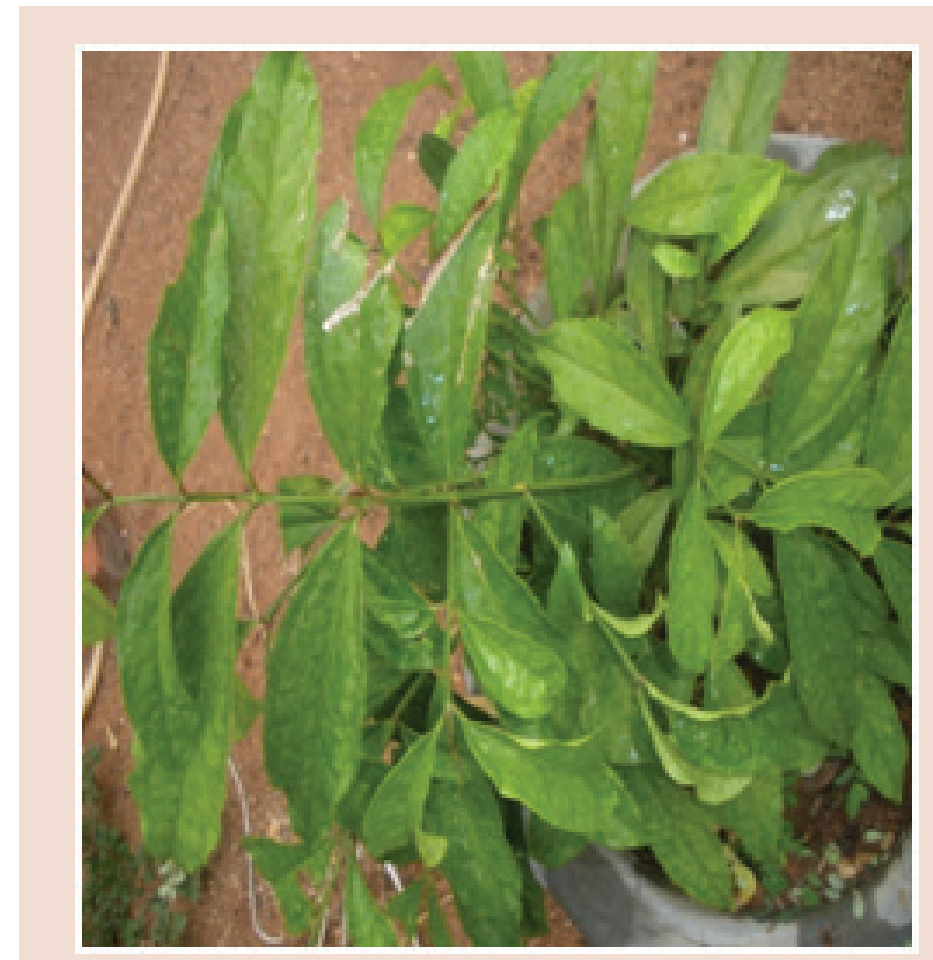

Figure 1: Photograph showing twig of Myxopyrum smilacifolium Blume. leaf
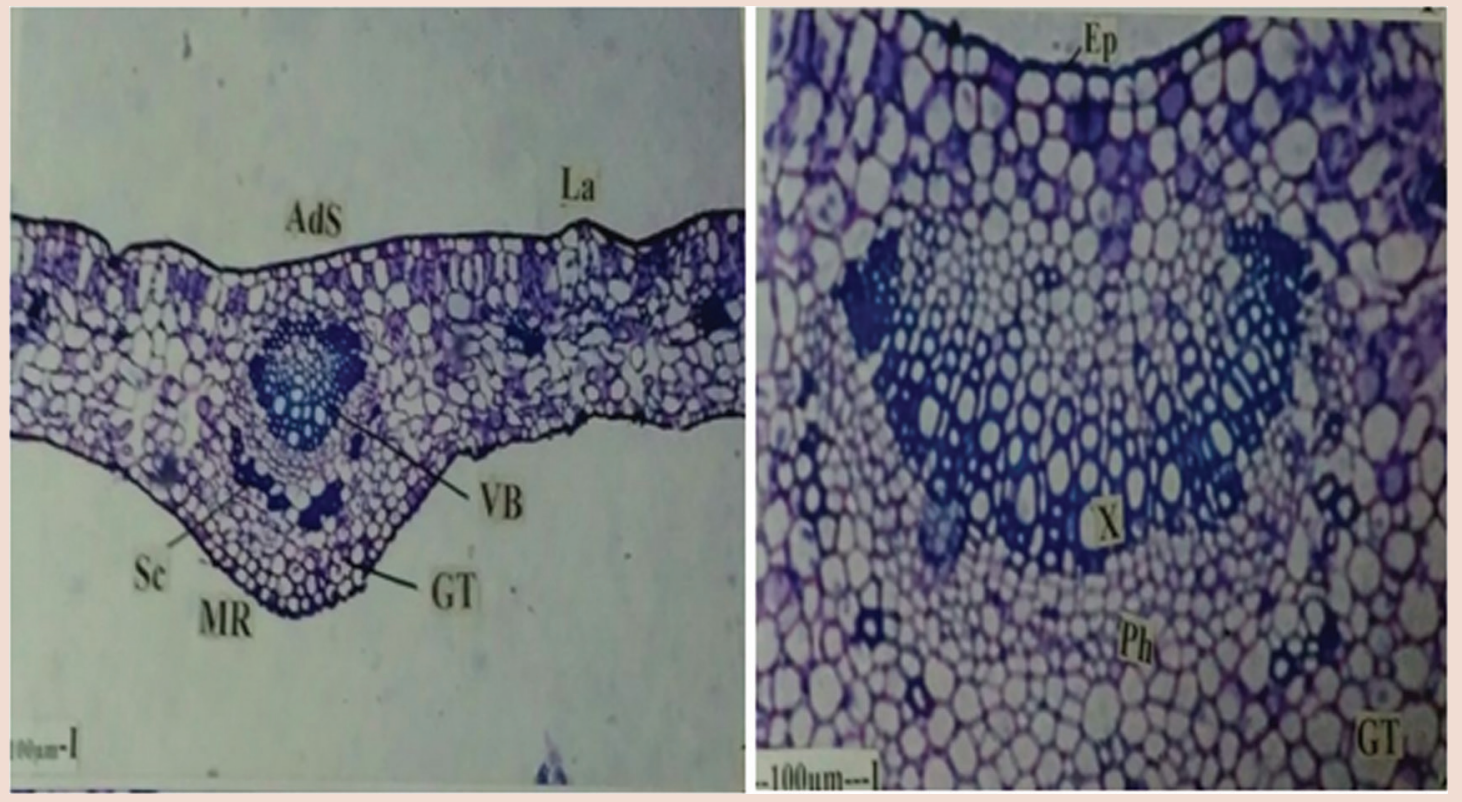

Figure 2: Photograph showing vascular bundle arrangement through midrib portion of leaf 

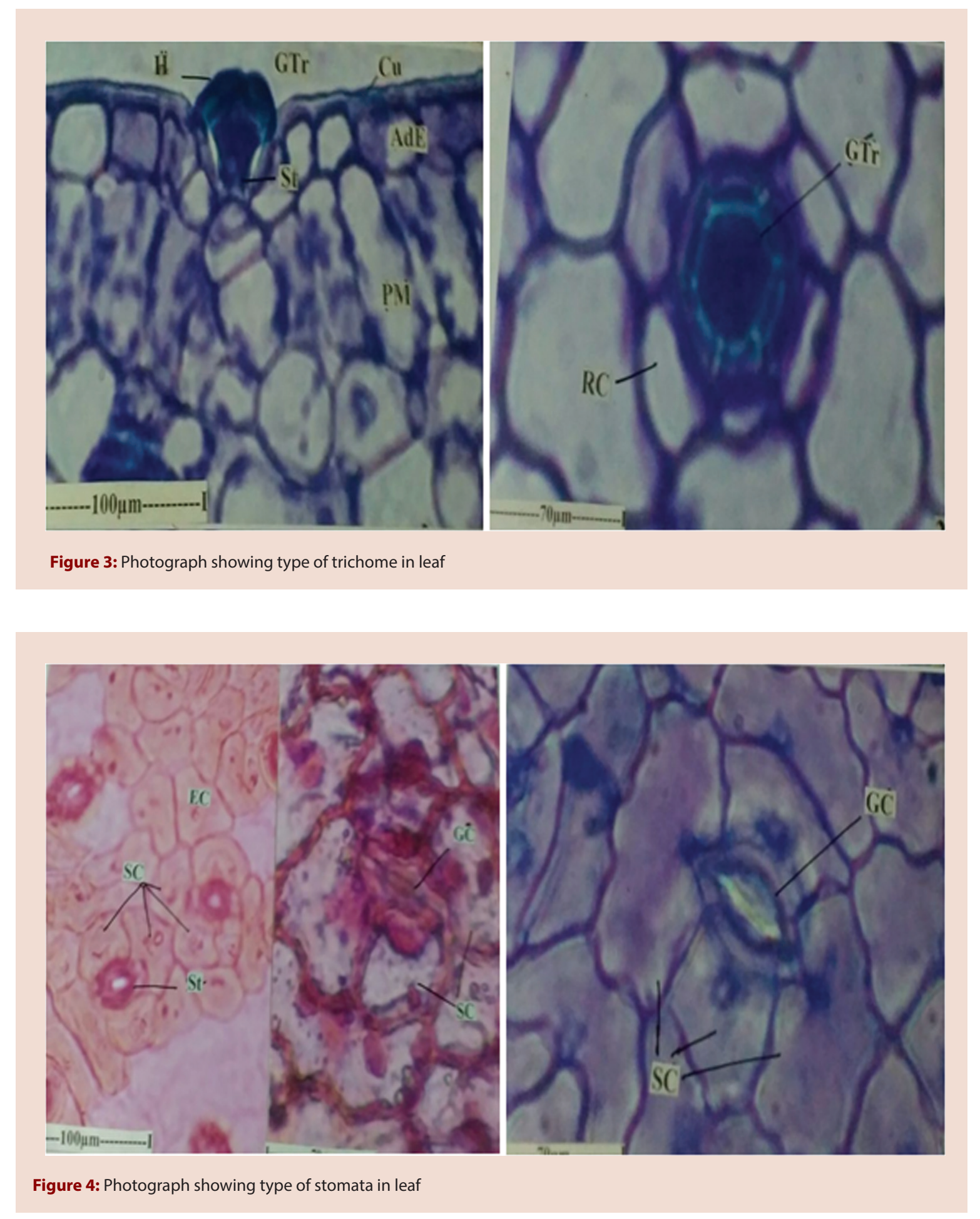

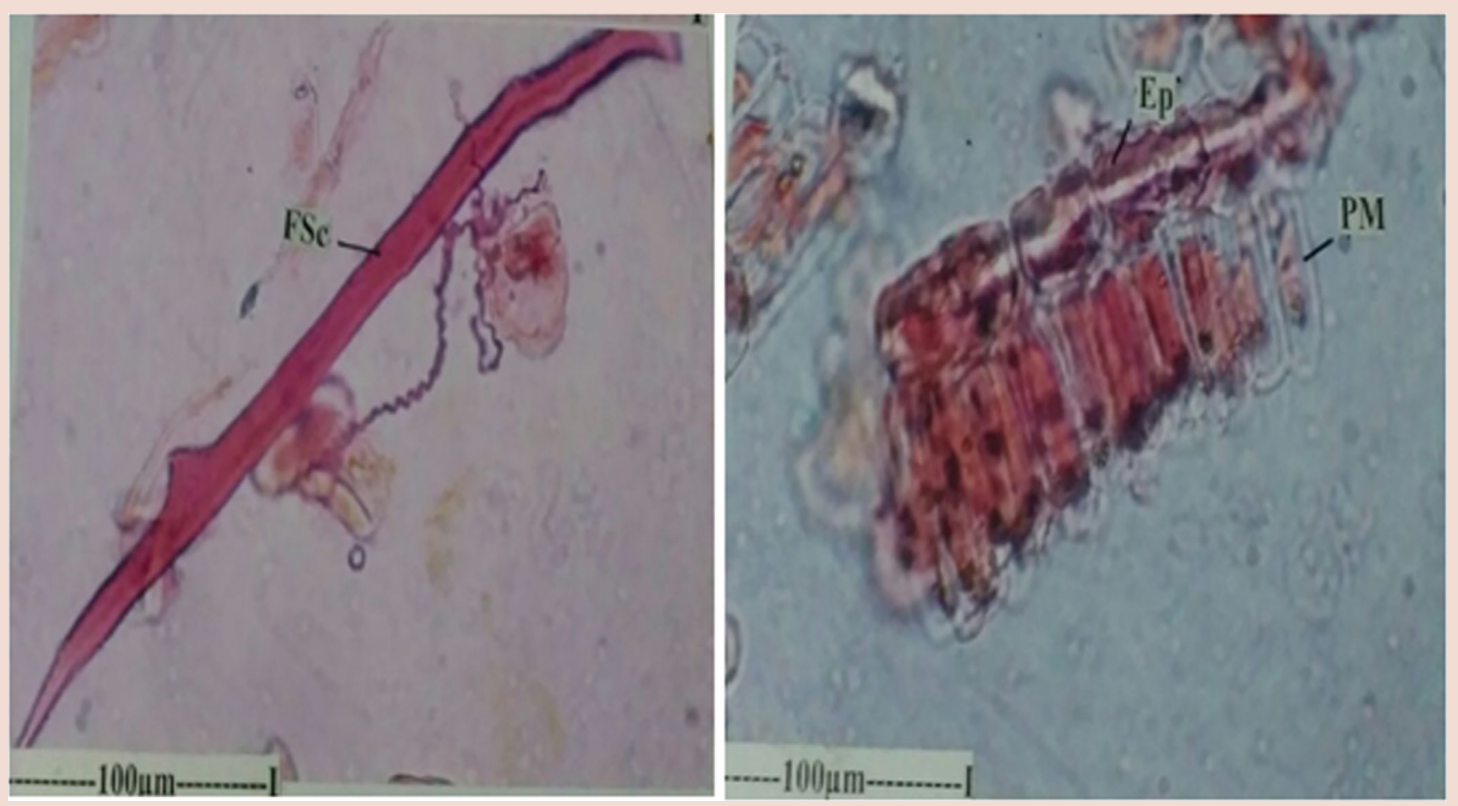

Figure 5: Photograph showing type powder characteristics of leaf

Table 1: Quantitative Microscopy of Myxopyrum smilacifolium Blume

\begin{tabular}{cc}
\hline Parameters & Values (mean) \\
\hline Stomatal number upper surface & 57.16 \\
Stomatal number lower surface & 76.17 \\
Vein Islet number & 11.30 \\
Vein Termination number & 12.40 \\
\hline
\end{tabular}

Table 2: Physicochemical parameters of leaf powder of Myxopyrum smilacifolium Blume

\begin{tabular}{cc}
\hline Parameters & Values $\% \mathrm{w} / \mathrm{w}$ \\
\hline Crude fiber & 32 \\
Moisture content (Loss on drying) & 10 \\
Total ash & 1.74 \\
Acid insoluble ash & 0.034 \\
Water soluble ash & 0.16 \\
Alcohol soluble extractive value & 1.36 \\
Water soluble extractive value & 15.14 \\
\hline
\end{tabular}

Table 3: Phytochemical analysis of various extracts of Myxopyrum smilacifolium Blume

\begin{tabular}{|c|c|c|c|c|c|}
\hline Phytoconstituents & Method & Aqueous Extract & Alcoholic Extract & Pet-ether Extract & Chloroform Extract \\
\hline \multirow{3}{*}{ Flavonoids } & Shinoda Test & - & - & - & - \\
\hline & Zn. Hydrocholride test & - & - & - & - \\
\hline & Lead acetate Test & - & - & - & - \\
\hline \multirow{2}{*}{ Alkaloids } & Wagner Test & + & + & - & + \\
\hline & Hager's Test & + & - & - & + \\
\hline \multirow{2}{*}{ Tanins \& Phenols } & $\mathrm{Fecl}_{2}$ Test & + & + & - & - \\
\hline & Potassium dichromate test & - & - & - & - \\
\hline Saponins & Foaming Test & + & + & + & + \\
\hline Terpenoids & Salkowski test & + & - & + & - \\
\hline Carbohydrates & Molish test & + & - & - & - \\
\hline Fixed oils & Cuso 4 Test & + & + & + & + \\
\hline Glycoside & Keller Killani Test & + & + & - & - \\
\hline
\end{tabular}

-Negative $=$ Absent; + Positive $=$ Present. 
Table 4: Flourescence analysis of Myxopyrum smilacifolium Blume

\begin{tabular}{|c|c|c|c|}
\hline \multirow{2}{*}{ Solvent used } & \multirow{2}{*}{ Visible light } & \multicolumn{2}{|c|}{ UV light } \\
\hline & & $254 \mathrm{~nm}$ & $366 \mathrm{~nm}$ \\
\hline Distilled water & Clear & Green & Green \\
\hline $1 \mathrm{~N} \mathrm{NaOH} 1 \mathrm{~N}$ Methanol & Fluorescent green & Dark Green & Blackish green \\
\hline $1 \mathrm{~N} \mathrm{HCl}$ & Brownish green & Olive green & Dark Green \\
\hline Ethanol & Fluorescent green & Bright green & Dark Green \\
\hline $50 \% \mathrm{HNO}_{3}$ & Greenish yellow & Grayish green & Moderate green \\
\hline $\mathrm{FeCl}_{3}$ & Brownish green & Greenish blue & Bluish green \\
\hline $\mathrm{CHCl}_{3}$ & Olive green & Grayish black & Blackish green \\
\hline Picric acid & Yellowish green & Yellowish green & Light greenish \\
\hline
\end{tabular}

leaves of Myxopyrum smilacifolium Blume had shown the presence of secondary metabolites which can play a vital role in medicine.

\section{ACKNOWLEDGEMENT}

We extend our sincere thanks to Dr. P. Jayaraman, Director, Retd, Professor, Presidency College, Chennai-5, for providing authenticated sample of M. Smilacifolium B.

\section{CONFLICT OF INTEREST}

We declare that we have no conflict of interest.

\section{ABBREVIATION USED}

cm: centimeters; mm: millimeters; hr: hour; B.: Blume; nm: nanometers; $\mathbf{N a O H}$ : Sodium hydroxide; $\mathbf{H C l}$ : Hydrochloric acid; $\mathbf{H N O}_{3}$ : Nitric acid; $\mathbf{C H C l}_{3}$ : Chloroform.

\section{REFERENCES}

1. Nadkarni KM. Indian Materia Medica. Vol. 1. Popular Prakhashan Pvt. Ltd., Bombay, India: 2009;2:1052.

2. Kiew R. The Genus Myxopyrum L. (Oleaceae). Blumea. 1984;29(2):499-512.
3. Henrik Franzyk, Soren Rosendal Jensen and Carl Erik Olsen. Iridoid Glucosides from Myxopyrum smilacifolium. J Nat Prod. 2001;64(5):632-3.

4. O'Brien TP, Eder N, Cull Mc. Polychromatic staining of plant cells walls by toluidine blue-O. Protoplasma. 1964;59(2):364-72.

5. Khandelwal KR, Practical Pharmacognosy, Edn 20, Nirali Prakashan (INDIA) Publications., Pune: 2010:23:1-25.9.

6. Wallis TE. Practical Pharmacognosy, $4^{\text {th }}$ ed. Pharma Med Press, Hyderabad, India. 2011:128-31.

7. The Ayurvedic Pharmacopoeia of India. Part I, Vol. III, Ist Ed. Published by controller of publication, Govt. of India, Ministry of health and family welfare, Department of Indian System of Medicine and Homeopathy, New Delhi. 2001;228-33.

8. Indian Pharmacopoeia, Vol. 1, $5^{\text {th }}$ ed., Govt. of India, Ministry of health \& Family welfare published by the Indian pharmacopoeia commission Ghaziabad, $2007 ; 78$.

9. Harborne JB. Methods of extraction and isolation. In: Phytochemical Methods Chapman \& Hall: London. 1998:60-6.

10. Harborne J.B., Phytochemical methods: A Guide to Modern Techniques of Plant Analysis, Springer Verlag., Berlin. 2005:128-55.

11. Mukherjee P.K., Quality Control of Herbal Drugs, Business Horizons (INDIA) Pharmaceutical Publications., New Delhi: 2002:529-33.

12. Kokate CK. Practical Pharmacognosy, Edn 4, Vallabh Prakashan., Pune: 2002:107-29.

13. Rangari V.D., Pharmacognosy and Phytochemistry, Career publications. Nashik: 2004:176-7.

\section{PICTORIAL ABSTRACT}

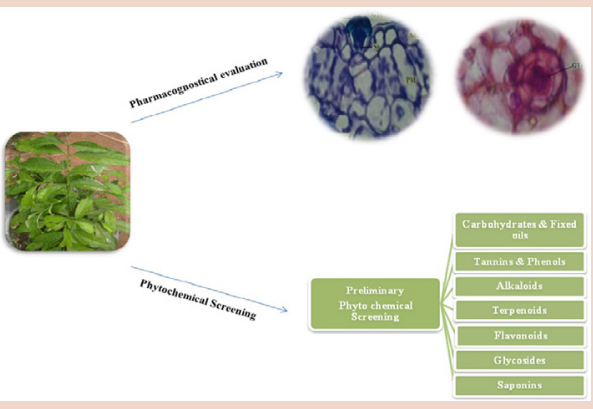

\section{SUMMARY}

- Leaves of Myxopyrum smilacifolium Blume was collected from Botanical garden, Kerala and authenticated.

- The microscopical evaluation revealed the presence of glandular trichomes and anamocytic stomata.

- The physical parameter viz., crude fibre content, ash values and extractive values were evaluated which is useful for standardization fo the crude drug

- The preliminary phytochemical screening of successive solvent extraction of leaves of Myxopyrum smilacifolium Blume shown the presence of alkaloids, glycosides, tannins, saponins, terpenoids, carbohydrates and fixed oils which can play a vital role in medicine.

\section{ABOUT AUTHOR}

Raveesha Peeriga: Is a research scholar at the JNTUA. Her research is focused on the pharmacognostical findings of Myxopyrum smilacifolium Blume.

K.B.Chandrasekar: Obtained his Ph. D. degree in 2000 from S.K. University, Anantapur. Currently, he is positioned as Director at JNTUA, Anantapur, Andhra Pradesh (India). He also got Best research paper award in the discipline of Pharmaceutical Chemistry 2005 from Indian drugs manufacturers association. 